\title{
Dynamics of solute/matric stress interactions with climate change abiotic factors on growth, gene expression and ochratoxin A production by Penicillium verrucosum on a wheat-based matrix
}

\author{
Shaimaa Abdelmohsen ${ }^{a}$, Carol Verheecke-Vaessen ${ }^{a}$, Esther Garcia-Cela ${ }^{a, b}$, Angel \\ Medina and Naresh Magan* \\ aApplied Mycology Group, Environment and AgriFood Theme, Cranfield University, \\ Cranfield, Beds. MK43 0AL, UK \\ ${ }^{b}$ Present address: School of Life and Medical Sciences, University of Hertfordshire, Hatfield, \\ Herts, AL10 9AB, UK. \\ *Corresponding author: n.magan@ cranfield.ac.uk
}

Corresponding author: Prof. N. Magan, Applied Mycology Group, Environment and AgriFood Theme, Cranfield University, Cranfield., Beds. MK43 0AL, UK. E.mail: n.magan@cranfield.ac.uk

\begin{abstract}
Penicillium verrucosum contaminates temperate cereals with ochratoxin A (OTA) during harvesting and storage. We examined the effect of temperature $\left(25 v s 30^{\circ} \mathrm{C}\right), \mathrm{CO}_{2}(400 v s 1000$ $\mathrm{ppm}$ ) and matric/solute stress (-2.8 vs $-7.0 \mathrm{MPa})$ on (i) growth, (ii) key OTA biosynthetic genes and (iii) OTA production on a milled wheat substrate. Growth was generally faster under matric than solute stress at $25^{\circ} \mathrm{C}$, regardless of $\mathrm{CO}_{2}$ concentrations. At $30^{\circ} \mathrm{C}$, growth of $P$. verrucosum was significantly reduced under solute stress in both $\mathrm{CO}_{2}$ treatments, with no growth observed at $-2.8 \mathrm{MPa}\left(=0.98\right.$ water activity, $\left.\mathrm{a}_{\mathrm{w}}\right)$ and $1000 \mathrm{ppm} \mathrm{CO}_{2}$. Overall, growth patterns under solute stress was slower in elevated $\mathrm{CO}_{2}$ than under matric stress when compared with existing conditions. The otapksPV gene expression was increased under elevated $\mathrm{CO}_{2}$ levels in matric stress treatments. There was fewer effects on the otanrpsPV biosynthetic gene. This pattern was paralleled with the production of OTA under these conditions. This suggest that $P$. verrucosum is able to actively grow and survive in both soil and on crop debris under three way interacting climate-related abiotic factors. This resilience suggests that they would still be able to pose an OTA contamination risk in temperate cereals post-harvest.
\end{abstract}

Keywords: water availability, mycotoxin, qPCR, biosynthetic genes, climate change scenarios, abiotic stress

\section{INTRODUCTION}

Penicillium verrucosum is a predominantly soil-based xerotolerant species that also survives saprophytically on crop residue. It colonises temperate cereal grains during harvesting and delayed drying or poor post-harvest management which can lead to ochratoxin A (OTA) contamination of pockets of under-dried or moist grain (Lund and Frisvad, 2003; Lindblad et al., 2004; Magan and Aldred, 2007). Indeed, because OTA is considered to be a nephrotoxin and potentially carcinogenic for human (International Agency for Cancer Research, 1993) there 
are legislative limits in cereals destined for food processing or for animal feed (European Union, 2006).

Previous ecological studies have shown that water availability, temperature and intergranular atmosphere and their interactions have an impact on growth and OTA production in vitro and in situ in stored wheat grain and identified the optimum and boundary conditions for growth and OTA production (Cairns et al., 2005). It has also been shown that populations of $P$. verrucosum predominantly reside in soil and on crop residue which form the focal points for the development of the inoculum for contaminating cereals during harvesting and drying (Elmholt, 2003; Elmholt and Hostbjerg, 1999). Thus, an understanding of the relative tolerance of $P$. verrucosum to both soil water stress, mainly determined by the soil matric potential, and solute stress in crop residue is important. Abdelmohsen et al. (2020) recently showed that optimum growth and OTA production were at $-7.0 \mathrm{MPa}\left(=0.95\right.$ water activity, $\left.\mathrm{a}_{\mathrm{w}}\right)$ and -1.4 $\mathrm{MPa}\left(=0.99 \mathrm{a}_{\mathrm{w}}\right)$ respectively, regardless of whether solute or matric stress were imposed on $P$. verrucosum. However, this species was more sensitive to ionic solute stress $(\mathrm{NaCl})$ with no growth at $-19.6 \mathrm{MPa}\left(=0.86 \mathrm{a}_{\mathrm{w}}\right)$ while growth still occurred in the presence of the non-ionic solute (glycerol) and matric stress treatments.

Previous studies with non-xerophilic toxigenic fungi such as Fusarium graminearum, and xerophilic/xerotolerant species such as Aspergillus ochraceus $(=A$. westerdijkiae) and $A$. flavus have examined the relative tolerance to matric vs solute stress (Ramos et al., 1999; Ramirez et al., 2004; Giorni et al., 2008). These showed that for the non-xerophilic species both macroconidial germination and growth were more sensitive to matric than solute stress. In contrast, the xerotolerant/xerophilic species were more resilient and able to tolerate both matric and solute stress (Magan, 1988; Magan et al., 1995; Ramos et al., 1999; Ramirez et al., 2004). Subsequently, Jurado et al. (2008) showed that the non-xerophilic mycotoxigenic species $F$. verticillioides, a pathogen of maize, grew relatively similarly under both ionic and non-ionic solute stress, but was also more sensitive to matric stress. The relative expression of the FUMI gene involved in fumonisins biosynthesis reflected these differences.

OTA is a polyketide mycotoxin, with the biosynthetic pathway predominantly elucidated in P. nordicum (Wang et al., 2016). In this species, the gene cluster for OTA includes those encoding for a polyketide synthase (PKS) (otapksPN) and non-ribosomal peptide synthetase (NRPS) (otanrpsPN). Geisen et al. (2004) correlated the relative expression of the otapksPN from $P$. nordicum with OTA production. There is a good homology between the OTA biosynthetic pathways in both $P$. nordicum and $P$. verrucosum, with some differences related to the function of the PKS gene (otapks) (Geisen et al., 2006; Wang et al., 2016). Abdelmohsen et al. (2020) were able to show that $P$. verrucosum was able to express the otapksPV over a wide range of ionic/non-ionic solute stress conditions (-1.4 to $-14.0 \mathrm{MPa}$; $\left.=0.99-0.90 \mathrm{a}_{\mathrm{w}}\right)$. Interestingly, the otanrpsPV gene was significantly up-regulated under matric stress, especially with relatively freely available water $\left(-1.4 \mathrm{MPa}=0.99 \mathrm{a}_{\mathrm{w}}\right)$. These studies focused on solute/matric stress and did not examine the effects of interactions with temperature or other abiotic factors.

There is now interest in the resilience of mycotoxigenic fungi to climate-related abiotic factors and whether this will stimulate or inhibit mycotoxin production. Such interacting factors have been shown to result in stimulation of biosynthetic genes involved in mycotoxin production and phenotypic toxin production including aflatoxins by $A$. flavus, OTA by $A$. westerdijkiae and T-2/HT-2 toxin by F. langsethiae (Akbar et al., 2016, 2020; Medina et al., 2017; Verheecke-Vaessen et al., 2019; Cervini et al., 2020). However, no studies have previously examined solute $v s$ matric stress when combined with changes in temperature and exposure to existing or elevated $\mathrm{CO}_{2}$ may have on growth, biosynthetic genes involved in toxin production and the amounts of toxin production. This may be important in understanding the potential changes in the life cycle and ecological characteristics of this species especially in 
soil and on crop debris which will influence the inoculum potential for contamination of cereals with OTA, especially in the harvesting, drying and post-harvest phases.

Thus, the objectives of this work were to examine the effect of solute or matric stress $\left(-2.8\right.$ or -7.0 MPA $\left(=0.98\right.$ and $\left.0.95 \mathrm{a}_{\mathrm{w}}\right)$, temperature $\left(25\right.$ or $\left.30{ }^{\circ} \mathrm{C}\right)$ and exposure to $\mathrm{CO}_{2}(400 \mathrm{vs}$ $1000 \mathrm{ppm}$ ) on: (a) growth, (b) relative expression of two key biosynthetic genes (otapksPV, otanrpsPV) involved in OTA biosynthesis and (c) OTA production by $P$. verrucosum on a milled wheat matrix.

\section{MATERIALS AND METHODS \\ Fungal strain}

A strain of $P$. verrucosum (OTA11) was used in these studies. This was isolated from wheat grain and is a known producer of OTA (Cairns et al., 2005; Abdelmohsen et al., 2020). We are grateful to Dr. Monica Olsen (National Food Authority, Sweden) for the supply of the strain.

\section{Inoculum preparation and inoculation}

The fungal strain was sub-cultured on malt extract agar $\left(30.0 \mathrm{~g} \mathrm{~L}^{-1}\right.$ malt extract, $5.0 \mathrm{~g}$ $\mathrm{L}^{-1}$ peptone and $15.0 \mathrm{~g} \mathrm{~L}^{-1}$ agar) at $25^{\circ} \mathrm{C}$ in the dark for up to 10 days. The spores were gently dislodged from the colony surface by using a surface sterilised loop and placing them into suspension in $9 \mathrm{ml}$ sterile distilled water containing $0.05 \%$ (v/v) Tween-80 in $25 \mathrm{ml}$ Universal bottles. The suspensions were shaken and then the spore concentration determined using a haemocytometer and adjusted to $10^{6}$ spore $\mathrm{ml}^{-1}$. This was used for inoculation by taking $0.1 \mathrm{ml}$ of an inoculum and spreading onto a $2 \%$ milled wheat agar medium which was incubated overnight at $25^{\circ} \mathrm{C}$. The germlings were then used as the inoculum and $4 \mathrm{~mm}$ agar discs were taken with a surface sterilised cork borer and used to centrally inoculate the treatment plates.

\section{Solute and matric potential modified media}

A basal 2\% (w/v) milled wheat agar medium was used in this study. This medium was modified to $-2.8\left(=0.98 \mathrm{a}_{\mathrm{w}}\right)$ and $-7.0 \mathrm{MPa}\left(=0.95 \mathrm{a}_{\mathrm{w}}\right)$ water potentials by using mixtures of the non-ionic solute glycerol + water (Abdelmohsen et al., 2020). The media were autoclaved at $121{ }^{\circ} \mathrm{C}$ and poured into $9 \mathrm{~cm}$ Petri plates (approx. $15 \mathrm{ml}$ ) and kept at $4{ }^{\circ} \mathrm{C}$ in separate plastic bags until used. The final $\mathrm{a}_{\mathrm{w}}$ levels were checked with an Aqua Lab TE4 (Decagon Devices. Pullman, WA, 99163, USA).

For modification of the matric potential, the agar was omitted and the $2 \%(\mathrm{w} / \mathrm{v})$ milled wheat was mixed with different amounts of PEG 8000 to obtain the target matric potentials detailed above. These matric potentials were checked using the Aqua Lab 4 TE. Previous studies have shown that the water potential generated by PEG 8000 is predominantly (99\%) due to matric forces (Steuter et al., 1981). The media were prepared in $9 \mathrm{~cm}$ Petri plates that contained a sterile circular $8.5 \mathrm{~cm}$ diameter disc of capillary matting. After decanting $15 \mathrm{ml}$ of the sterile cooled $2 \%(\mathrm{w} / \mathrm{v})$ wheat broth medium into the Petri plates they were then overlayed with sterile circular layers $8.5 \mathrm{~cm}$ diameter of polyester fibre and then a sterile cellophane layer. This method has been detailed previously (Jurado et al., 2008). The different treatments were kept in different polyethylene bags at $4{ }^{\circ} \mathrm{C}$ and kept closed to avoid moisture loss and changes in solute/matric potential regimes. These were removed and equilibrate at $25{ }^{\circ} \mathrm{C}$ before they were centrally inoculated as described previously. The inoculated solute and matric stress treatments and replicates were incubated at either 25 or $30^{\circ} \mathrm{C}$ in the environmental chambers. 


\section{Effect of interacting climate-related abiotic conditions on $\mathrm{P}$. verrucosum growth/OTA production in relation to solute and matric imposed water stress.}

The different treatments and replicates were placed in separate $13 \mathrm{~L}$ plastic environmental chambers (Verheecke-Vaessen et al., 2019). These chambers also contained inlet and outlet valves at each end. The chambers contained glycerol/water solutions $(2 \times 500$ $\mathrm{mls}$ ) to maintain the equilibrium relative humidity (erh) of the atmosphere within the individual chambers at the target water potential levels. The chambers were flushed with either synthetic air or $1000 \mathrm{ppm} \mathrm{CO}_{2}$ daily for 10 days. The gas cylinders contained either $400 \mathrm{ppm} \mathrm{CO}_{2}$ (ambient air) or a speciality gas of 1000 ppm $\mathrm{CO}_{2}$ (certified gas; British Oxygen Company, Guildford, Surrey, U.K.). The environmental chambers were flushed at $3 \mathrm{~L} \mathrm{~min}^{-1}$ to replace $3 \mathrm{x}$ the volume of the incubation chamber every $24 \mathrm{hrs}$ and incubated at the target temperatures.

\section{Growth assessment}

Colony diameters of 4-5 replicate plates were measured in two directions at right angles to each other. Measurements were recorded daily or as required for up to ten days. The growth rate was calculated by plotting the radial mycelial growth against time and the linear regression of the slope of the linear growth phase was used to obtain the radial growth rates ( $\mathrm{mm} \mathrm{day}^{-1}$, Medina and Magan, 2010).

\section{Isolation of total RNA}

The fungal biomass was harvested after 10 days incubation in the presence of liquid nitrogen to keep the integrity of the RNA and stored at $-80^{\circ} \mathrm{C}$ for molecular work, and $-20^{\circ} \mathrm{C}$ for OTA analysis.

The fungal cell walls were disrupted using the bead-beating method recommended by Leite et al. (2012). The RNA was extracted using the Total RNA Spectrum Plant Kit (Sigma, UK) following the manufacturers protocol. To remove genomic DNA contamination, samples were treated with an on-column DNase digestion using the RNase-Free DNase Set Kit (Qiagen, $\mathrm{UK})$. The RNA concentration and purity $\left(\mathrm{A}_{260} / \mathrm{A}_{280}\right.$ ratio $) \&\left(\mathrm{~A}_{260} / \mathrm{A}_{230}\right.$ ratio $)$ were determined spectrophotometrically using a $2.5 \mu \mathrm{L}$ aliquot on the Picodrop (Spectra Services Inc., USA). For checking the RNA integrity, the Experion ${ }^{\mathrm{TM}}$ Automated Electrophoresis System using the Experion RNA StdSens analysis kits (Bio-Rad Laboratories Ltd., Hertfordshire, UK) was used, where the RQI that the minimum quality control was set at RQI $>7$.

\section{$R T-q P C R$ assays and relative quantification}

RT-qPCR assays were used to amplify the otapksPV and otanrpsPV genes, with the Btubulin gene used as the reference.

(a) Primers: The primer pairs PV-bentaqfor/rev, previously designed from the otanrpsPV gene involved in the OTA biosynthetic pathway (Rodríguez et al., 2011) and the $\beta$-tubulin gene (Leite, 2013) were used. Nucleotide sequences of primers used in the RT-qPCR assays are detailed in Table 1.

(b) Relative Gene Expression: Relative quantification of the expression of otapksPV and otanrps $\mathrm{Pv}$ genes was performed using the reference $\beta$-tubulin gene. To calculate the $\Delta \mathrm{Cq}, \mathrm{Cq}$ of the gene of interest was subtracted from the $\mathrm{Cq}$ of the reference gene (Rodriguez et al., 2014). Subsequently, for $\Delta \Delta \mathrm{Cq}$, the non-modified medium used as a control.

\section{Quantification of OTA production}


The treatments were harvested after 10 days. For solute stress treatments $5(5 \mathrm{~mm}$ diameter) plugs were taken across the colony using a sterile cork borer. For matric stress treatments biomass was taken from the cellophane surface and combined with 1-2 mls of medium below the colony area. The samples were placed into $2 \mathrm{~mL}$ Eppendorf tubes and weighed. OTA was extracted by adding $1 \mathrm{~mL}$ HPLC grade methanol and shaken for 1 hour at $200 \mathrm{rpm}$ at $25^{\circ} \mathrm{C}$. The medium and biomass were separated from the extraction solvent by centrifugation for $10 \mathrm{~min}$ at $15000 \mathrm{x} \mathrm{g}$. The extracts were filtered through a $0.22 \mu \mathrm{m}$ (type PTFE) filter directly into amber HPLC vials. The conditions for OTA detection and quantification were as follows:

Mobile Phase

Column

Temperature of column

FLD Excitation wavelength

FLD Emission wavelength

Flow rate

Retention time

Run time

Limit of Detection:

Limit of Quantification:
Acetonitrile (57\%):Water (41\%):Acetic acid (2\%)

$\mathrm{C}_{18}$ column (Poroshell 120, length $100 \mathrm{~mm}$, diameter $4.6 \mathrm{~mm}$, particle size 2.7 micron).

$25{ }^{\circ} \mathrm{C}$

$330 \mathrm{~nm}$

$460 \mathrm{~nm}$

$1 \mathrm{ml} \mathrm{min}{ }^{-1}$

$2.6 \mathrm{~min}$

$13 \mathrm{~min}$

$2.83 \mathrm{ng} \mathrm{g}^{-1}$

$9.43 \mathrm{ng} \mathrm{g}^{-1}$

The OTA was analysed using HPLC-FLD by including OTA standards at different concentrations with each batch and their peaks detected by Agilent Chem-Station software Ver. B Rev: 03.01 [317] (Agilent Technologies, Palo Alto, CA, USA). Comparisons were made between the standard curve and the different treatments and replicates (Abdelmohsen et al., 2020).

\section{Statistical analysis}

Each treatment was carried out with 4-5 replicates for growth rate assessment, gene expression and OTA production and repeated once. The normality was checked using the Shapiro test and homoscedasticity was checked using the Levene test. The factors and responses were examined using the Kruskall-Wallis (non-parametric) when the data were not normally distributed. For normally distributed data, the data sets were analysed using ANOVA in JMP® 14 (SAS Institute Inc., 2016. Cary, NC, USA). The statistical significant level was set at $p<0.05$ for all single and interacting treatments.

\section{RESULTS}

Effect of climate change-related interacting factors on relative growth rates at $25^{\circ} \mathrm{C}$ and 30 ${ }^{\circ} \mathrm{C}$ on wheat-based matrices

Figure 1a, b compares the effect of matric and solute stress, temperature $\left(25\right.$ and $\left.30{ }^{\circ} \mathrm{C}\right)$ and $\mathrm{CO}_{2}$ exposure (400 or $1000 \mathrm{ppm}$ ) on the relative growth of the $P$. verrucosum strain. Growth was significantly affected when exposed to $30^{\circ} \mathrm{C}$ and $-2.8 \mathrm{MPa}\left(=0.98 \mathrm{a}_{\mathrm{w}}\right)$ and 1000 ppm $\mathrm{CO}_{2}$ where no growth occurred in the solute stress treatment. However, at -7.0 MPa (0.95 $\mathrm{a}_{\mathrm{w}}$ ) and $1000 \mathrm{ppm} \mathrm{CO}_{2}$ there was an increased growth rate when compared to existing conditions. With matric stress there was no effect on growth, with similar colonisation rates under all the treatments at $30{ }^{\circ} \mathrm{C}$ (Figure $1 \mathrm{~b}$ ).

Statistically, the impact of treatments showed that there was a significant effect of the different individual abiotic factors on growth at $25^{\circ} \mathrm{C}$. At $30^{\circ} \mathrm{C}$, with solute imposed stress, there was a significant effect when exposed to $1000 \mathrm{ppm} \mathrm{CO}_{2}$ at $-2.8 \mathrm{MPa}$ water potential $\left(=0.98 \mathrm{a}_{\mathrm{w}}\right)$ as no growth was observed. 
Table 1. Nucleotide sequences of primers for RT-qPCR assays

\begin{tabular}{|c|c|c|c|c|}
\hline $\begin{array}{l}\text { Primer } \\
\text { pairs }\end{array}$ & Gene & Nucleotide sequences $\left(5^{\prime}-3^{\prime}\right)$ & $\begin{array}{l}\text { Product } \\
\text { size }(\mathrm{pb})\end{array}$ & Publication \\
\hline $\begin{array}{c}\text { PV- } \\
\text { bentaq-for }\end{array}$ & ß-tubulin & CTAGGCCAGCGCTGACAAGT & 63 & Leite, \\
\hline $\begin{array}{c}\text { PV- } \\
\text { bentaq-rev }\end{array}$ & ß-tubulin & CTAGGTACCGGGCTCCAA & 63 & $(2013)$ \\
\hline \multicolumn{5}{|l|}{ otapksPV } \\
\hline -for & otapksPV & TTGCGAATCAGGGTCCAAGTA & 1080 & $\begin{array}{l}\text { Schmidt- } \\
\text { Heydt et al. } \\
(2007)\end{array}$ \\
\hline $\begin{array}{c}\text { otapksPV } \\
\text {-rev }\end{array}$ & otapksPV & CGAGCATCGAAAGCAAAAACA & 1080 & \\
\hline $\begin{array}{c}\text { otanprsPV } \\
\text {-for }\end{array}$ & otanrpsPV & GCCATCTCCAAACTCAAGCGTG & 699 & $\begin{array}{c}\text { Rodriguez } \\
\text { et al. } \\
\text { (2011) }\end{array}$ \\
\hline $\begin{array}{c}\text { otanprsPV } \\
\text {-rev } \\
\end{array}$ & otanrpsPV & GCCGCCCTCTGTCATTCCAAG & 699 & \\
\hline
\end{tabular}
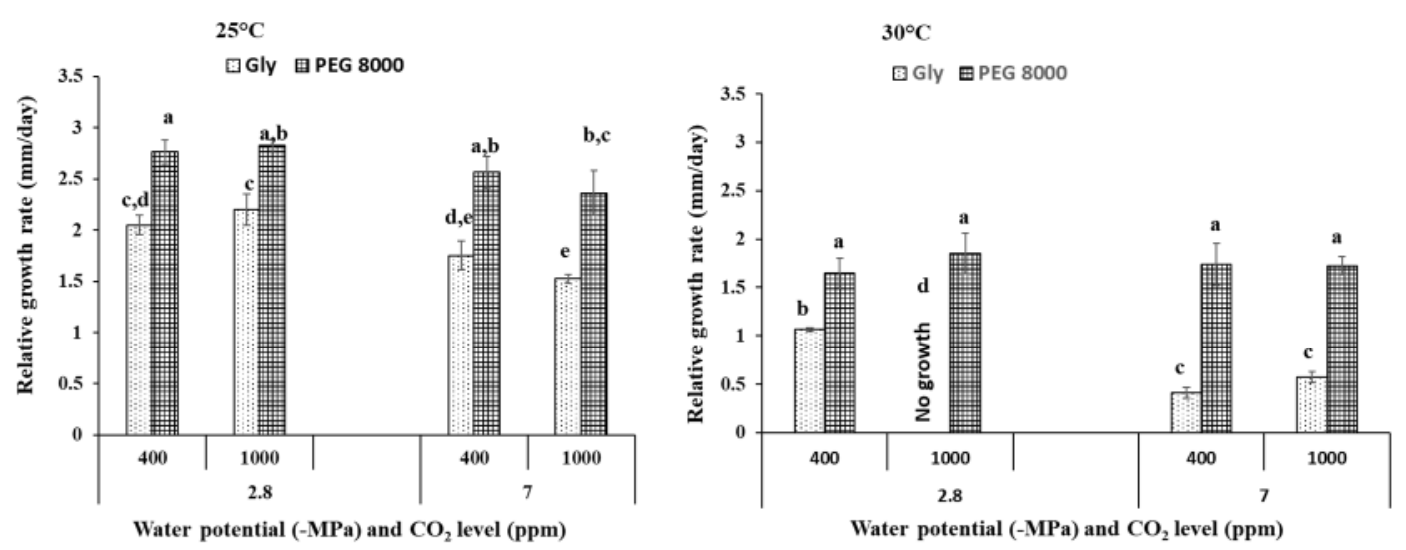

Figure 1. Effect of solute or matric potential stress $\mathrm{x} \mathrm{CO}_{2}(400$ or $1000 \mathrm{ppm}) \mathrm{x}$ temperature ( 25 and $30{ }^{\circ} \mathrm{C}$ ) on relative growth rate of $P$. verrucosum grown on wheat-based media modified with glycerol (non-ionic solute potential) or PEG 8000 (matric potential) after 10 days growth on milled wheat media. Different letters indicate significant differences between treatments. 


\section{Effect of climate change-related abiotic factors on two biosynthetic genes involved in ochratoxin A production on a wheat-based matrix}

Effects on otapksPV gene expression: At $25^{\circ} \mathrm{C}$, the pattern of gene expression at the two water stress levels in the different media was quite different (Figure 2). Under solute stress, at $-2.8 \mathrm{MPa}$ water potential $\left(=0.98 \mathrm{a}_{\mathrm{w}}\right)$, the gene expression was increased at $1000 \mathrm{ppm}$ when compared to the existing conditions. However, under matric stress, the gene expression was lower in the $1000 \mathrm{ppm} \mathrm{CO}_{2}$ and water stress treatment of $-7.0 \mathrm{MPa}\left(=0.95 \mathrm{a}_{\mathrm{w}}\right)$ when compared to existing conditions.

Statistically, the imposed water stress and type of solute stress had a significant effect on the relative otapks gene expression at $25{ }^{\circ} \mathrm{C}$. However, exposure to elevated $\mathrm{CO}_{2}$ levels showed no significant influence on this toxin biosynthetic gene, which remained constant, regardless of the imposed solute or matric stress (Figure 2a).

However, at $30{ }^{\circ} \mathrm{C}$, the pattern of expression of this gene suggested more resilience and tolerance to the interacting abiotic stresses imposed. Under matric stress, especially at $-7.0 \mathrm{MPa}$ $\left(=0.95 \mathrm{a}_{\mathrm{w}}\right)$ there was a significant effect on growth, especially at elevated $\mathrm{CO}_{2}(1000 \mathrm{ppm})$ conditions (Figure 2b).

Effects on otanrpsPV gene expression: The expression of the otanrps gene involved in OTA biosynthesis, had expression patterns consistent with that of the otapks gene under matric potential stress (Figure 3a). In contrast, very low gene expression occurred in the solute stress treatments. Statistically, the expression of this gene was significantly reduced when $P$. verrucosum was exposed to elevated $\mathrm{CO}_{2}(1000 \mathrm{ppm})$ under water stress of $-7.0 \mathrm{MPa}(=0.95$ $\mathrm{a}_{\mathrm{w}}$ ) at $25^{\circ} \mathrm{C}$. At $30^{\circ} \mathrm{C}$, the gene expression remained constant, but decreased significantly under elevated $\mathrm{CO}_{2}$ and increased water stress, especially in the matric potential modified treatments (Figure 3b).
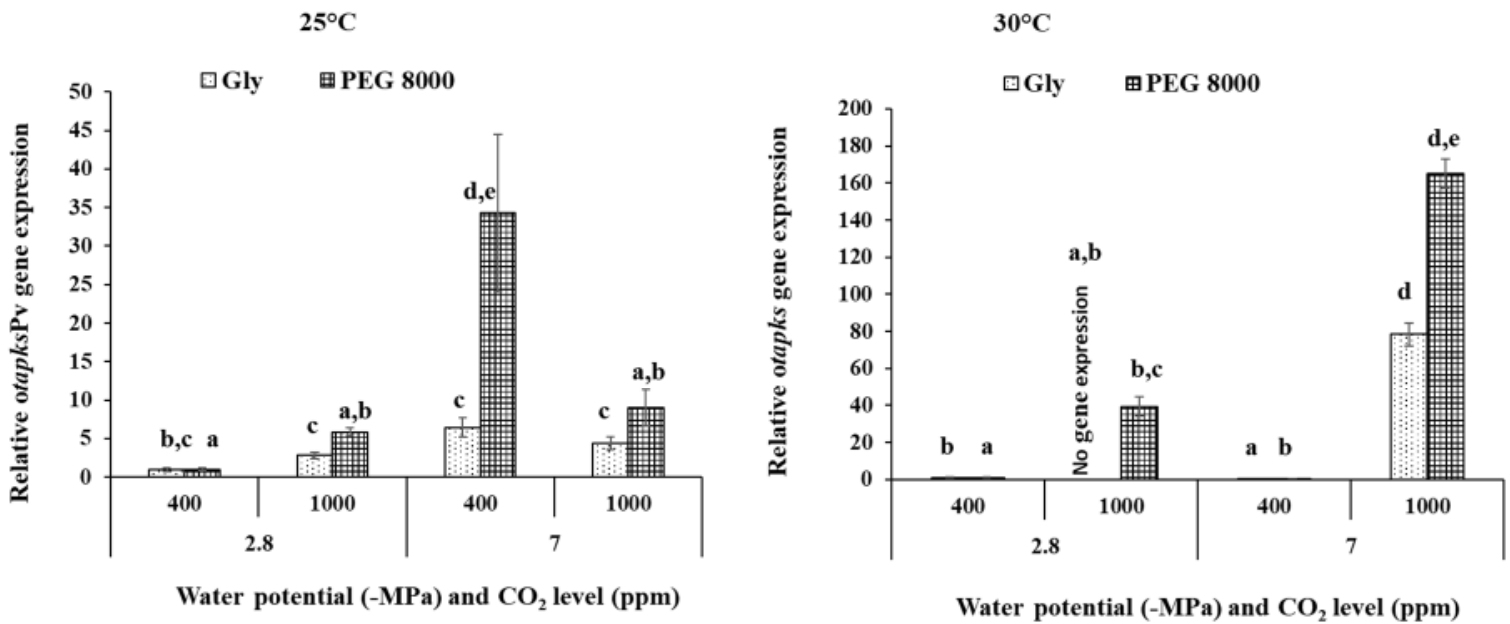

Figure 2. Abdelmohsen et. al.

Figure 2. Effect of solute or matric potential stress $\mathrm{x} \mathrm{CO}_{2}(400$ or $1000 \mathrm{ppm}) \mathrm{x}$ temperature $\left(25\right.$ and $30^{\circ} \mathrm{C}$ ) on relative otapksPV gene expression of $P$. verrucosum grown on the milled wheat-based media for 10 days. Comparisons were made with the control treatment of $400 \mathrm{ppm}$ $\mathrm{CO}_{2}$ and $-2.8 \mathrm{MPa}\left(=0.98 \mathrm{a}_{\mathrm{w}}\right)$ as the calibrator for each medium separately. Different letters indicate significant differences between the treatments. 

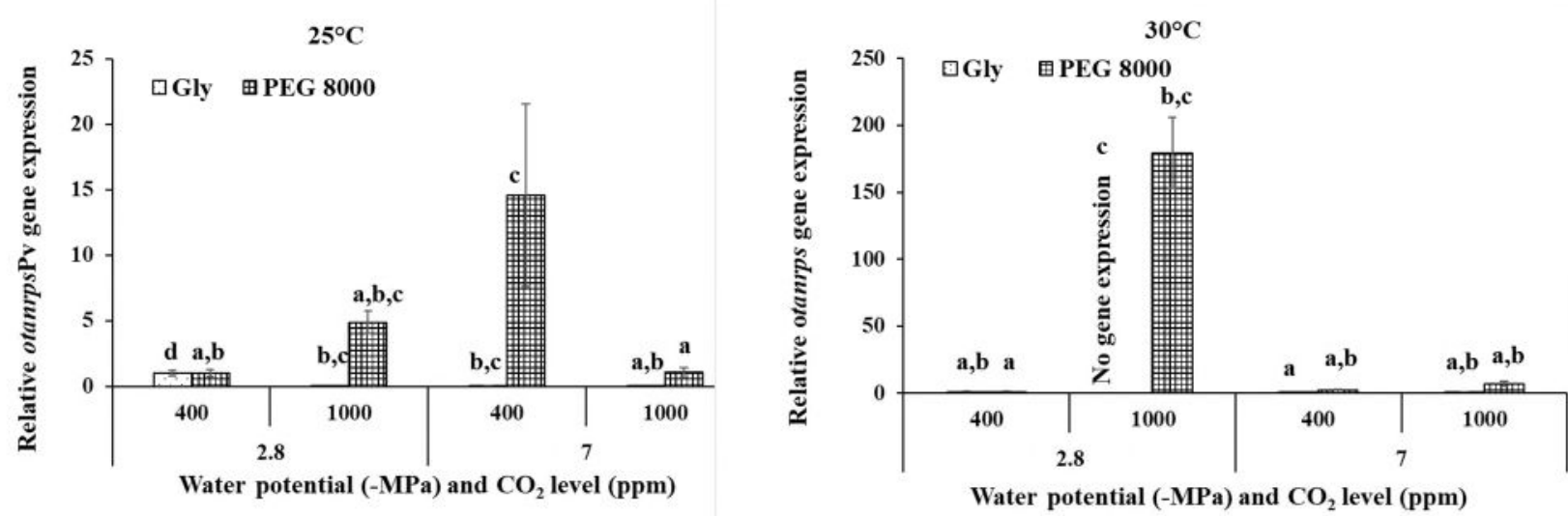

Figure 3. Effect of solute or matric potential stress $\mathrm{x} \mathrm{CO}_{2}(400$ or $1000 \mathrm{ppm}) \mathrm{x}$ temperature $\left(25\right.$ and $30^{\circ} \mathrm{C}$ ) on relative otanrpsPV gene expression of $P$. verrucosum grown on the milled wheat media for 10 days. The control treatment $\left(400 \mathrm{ppm} \mathrm{CO}_{2},-2.8 \mathrm{MPa}\right.$ water potential (= $0.98 \mathrm{a}_{\mathrm{w}}$ ) used as a calibrator for each medium separately. Different letters indicate significant difference between treatments.

\section{Effect of climate change-related abiotic factors on OTA production by $P$. verrucosum}

The concentrations of OTA $\left(\mu \mathrm{g} \mathrm{g}^{-1}\right)$ produced by the $P$. verrucosum cultures when grown on wheat-based media in elevated $\mathrm{CO}_{2}$ showed differences in tolerance to the imposed types of water stress (Table 2). This strain was more tolerant of matric stress with a consistently higher toxin production pattern regardless of water potential and $\mathrm{CO}_{2}$ concentrations at $25^{\circ} \mathrm{C}$. However, in the solute stress-modified media, very low amounts of OTA was detected.

At $30^{\circ} \mathrm{C}$, tolerance of $P$. verrucosum to matric imposed stress resulted in a stimulation of OTA in the $1000 \mathrm{ppm} \mathrm{CO}_{2}$ exposure treatment when compared to that in air (400 ppm; Table 3). Statistically, single factors and some two-way interacting factors such as solute type $x$ temperature and water potential x solute type were significant (Table 3). However, all the threeway climate-related interacting abiotic factors showed no significant effects on toxin production.

Table 2. Effect of solute/matric potential stress $\mathrm{x}$ elevated $\mathrm{CO}_{2} \mathrm{x}$ temperature on OTA production $(\mu \mathrm{g} / \mathrm{g})$ on wheat-based media modified with glycerol (solute) or PEG 8000 (matric potential stress) after 10 days incubation.

\begin{tabular}{|c|c|c|c|c|c|}
\hline $\begin{array}{c}\text { Water } \\
\text { potential } \\
\text { (-MPa) }\end{array}$ & $\begin{array}{c}\mathrm{CO}_{2} \\
\text { level } \\
\text { (ppm) }\end{array}$ & $\begin{array}{c}\text { Solute } \\
\text { stress } \\
\text { (Glycerol- } \\
\text { amended } \\
\text { media }\end{array}$ & $\begin{array}{c}\text { Matric Stress } \\
\text { (PEG 8000- } \\
\text { amended } \\
\text { media }\end{array}$ & $\begin{array}{c}\text { Solute } \\
\text { stress } \\
\text { (Glycerol- } \\
\text { amended } \\
\text { media }\end{array}$ & $\begin{array}{c}\text { Matric } \\
\text { stress } \\
\text { (PEG } \\
\text { 8000- } \\
\text { modified } \\
\text { media }\end{array}$ \\
\hline
\end{tabular}




\begin{tabular}{ccccccc}
\hline & 400 & $0.75 \pm 0.17$ & $55.74 \pm 39.75$ & $0.04 \pm 0.01$ & $2.05 \pm 1.40$ \\
& 1000 & $0.04 \pm 0.03$ & $83.55 \pm 14.16$ & ND* & $1.92 \pm 0.65$ \\
& & & & & \\
& 4.0 & & & & & \\
& 1000 & $0.06 \pm 0.01$ & $156.00 \pm 90.90$ & $0.16 \pm 0.03$ & $0.93 \pm 0.46$ \\
\hline
\end{tabular}

*ND: not determined because of no growth

Table 3. Summary statistical analyses for the effect of interacting climate-related abiotic factors on ochratoxin A production in relation to single, two-, three- and four-way interactions between factors. The probability values in bold were significant $(p<0.05)$. Based on ANOVA results for the effects of water potential, type of water potential (non-ionic solute; matric), $\mathrm{CO}_{2}$ level (400 ppm, $1000 \mathrm{ppm})$ and temperature $\left(25,30^{\circ} \mathrm{C}\right)$ were analysed.

\begin{tabular}{lc}
\hline Factor & Significance $(\boldsymbol{p}<\mathbf{0 . 0 5})$ \\
\hline Water potential & $\mathbf{0 . 0 2 6 1}$ \\
Solute type & $\mathbf{< . 0 0 0 1}$ \\
Temperature (temp) & $\mathbf{0 . 0 0 1 0}$ \\
$\mathrm{CO}_{2}$ & 0.2180 \\
Solute type x temp & $\mathbf{0 . 0 0 1 0}$ \\
Water potential x solute type & $\mathbf{0 . 0 2 4 0}$ \\
$\mathrm{CO}_{2}$ x temp & 0.3609 \\
$\mathrm{CO}_{2}$ x solute type & 0.2180 \\
Solute type x temp x $\mathrm{CO}_{2}$ & 0.3609 \\
Water potential x temp x solute type & 0.1066 \\
Water potential x temp x CO & 0.3494 \\
Water potential x solute type x $\mathrm{CO}_{2}$ & 0.1824 \\
Water potential x $\mathrm{CO}_{2} \times$ solute type x temp & 0.3402 \\
\end{tabular}

\section{Discussion}

This study has examined the effect of different types of water stress and their interaction with other climate change-related scenarios on the molecular ecology of $P$. verrucosum. To our knowledge, no previous studies have addressed this in the context of resilience of such mycotoxigenic fungi in relation to interacting abiotic stresses relevant to activity in soil and on crop residue. This OTA producing strain was able to grow at both the tested solute and matric imposed stress conditions $(-2.8,-7.0 \mathrm{MPa})$ with no significant differences between exposure to existing and elevated $\mathrm{CO}_{2}$ at $25^{\circ} \mathrm{C}$. However, when temperature was elevated by $+5{ }^{\circ} \mathrm{C}$, the growth pattern was different in both water stress treatments. In the solute-modified wheat media, growth was decreased significantly in the elevated $\mathrm{CO}_{2}$ treatments with no growth observed in the $1000 \mathrm{ppm}$, and $-2.8 \mathrm{MPa}\left(=0.98 \mathrm{a}_{\mathrm{w}}\right)$ treatment. The general pattern of growth was lower than at $25^{\circ} \mathrm{C}$. However, under matric potential stress, growth was faster, regardless of the water stress level or $\mathrm{CO}_{2}$ level. $P$. verrucosum is normally considered to be a problem in temperate cereals in cooler climatic regions. 
The present study and previous study by Abdelmohsen et al. (2020) suggest that certainly at $\leq 25^{\circ} \mathrm{C}$ this species will remain active and colonise both soil and cereal crop residue effectively because of the tolerance of both matric and solute stress. However, at $30{ }^{\circ} \mathrm{C}$, inoculum potential may be reduced in crop residue because of the lack of resilience to solute stress shown in the present study. However, under matric stress in both existing and elevated $\mathrm{CO}_{2}$ conditions this species is very resilient and soil may be a more important reservoir for the inoculum of this species than crop debris.

Previous studies have suggested that soil populations of $P$. verrucosum can vary between 100-300 CFUs $\mathrm{g}^{-1}$ soil, and is very competitive in the soil and crop residue niches (Elmholt, 2003; Elmholt and Hostbjerg, 1999). However, these studies did not examine the impact of solute and matric stress on the $P$. verrucosum populations. Studies by Magan (1988) examined both in vitro and in situ effects of solute and matric stress on germination on cereal straw certainly showed that soil fungi, including both Fusarium and Penicillium species, had a relatively good tolerance to both types of imposed water stress, although interactions with $\mathrm{CO}_{2}$ were not investigated. The present study suggests that under climate-related abiotic factors ecological competence will be conserved better in soil than on crop residue under climaterelated interacting abiotic factors.

For the biosynthetic genes involved in OTA production, the otapks and otanrps gene expression patterns appeared to be only slightly affected by the elevated $\mathrm{CO}_{2}$ treatment, especially at $25{ }^{\circ} \mathrm{C}$. Interestingly, under solute stress with existing or elevated $\mathrm{CO}_{2}$ the expression of both otapksPV and otanrps PV genes were very low with no expression recorded at intermediate water stress level of $-2.8 \mathrm{MPa}\left(=0.98 \mathrm{a}_{\mathrm{w}}\right)$ and $1000 \mathrm{ppm}$. However, at $-7.0 \mathrm{MPa}$ $\left(=0.95 \mathrm{a}_{\mathrm{w}}\right)$ relative otapksPV expression was significantly increased in the $1000 \mathrm{ppm} \mathrm{CO}_{2}$ exposure treatment. Previously, for other mycotoxigenic fungi such as A. flavus it was found that for the former species the aflD (structural gene) and aflR (regulatory gene) were stimulated under elevated temperatures and $\mathrm{CO}_{2}$ conditions in maize-based media and in stored maize (Medina et al., 2017; Garcia-Cela et al., 2020). Verheecke-Vaessen et al. (2019) showed that for Fusarium langsethiae both the TRI5 gene and T-2/HT-2 toxin production are stimulated under interacting climate-related abiotic factors. Cervini et al. (2020) in studies with strains of A. carbonarius, an OTA producer in grapes and vine fruits, showed that under solute stress conditions imposed with the non-ionic solute glycerol, cycles of increased day/night temperatures and elevated $\mathrm{CO}_{2}(1000 \mathrm{ppm})$ resulted in a stimulation of both structural genes (AcOTApks, AcOTAnrps, AcOTAhal, AcOTAp450, AcOTAbZIP) and regulatory genes ( $L a e A / V e A / V e l B$, "so called velvet complex") in the biosynthetic pathway of OTA. They suggested that this could increase the risks of OTA contamination in the wine production chain in southern Italy under climate-related abiotic changes. However, interactions with matric stress would provide more information on effects on the inoculum potential of this species, especially in soil. The stimulation observed is similar to that seen with other chemically related stresses. For example, the effect of intermediate concentrations of food grade preservatives on growth, otapksPV expression and OTA production found similar responses. Intermediate concentrations of calcium propionate or potassium sorbate resulted in a stimulation of otapksPV and OTA production under different ionic and non-ionic solute stress (SchmidtHeydt et al., 2007; 2008).

OTA production was also influenced by the imposition of climate-related abiotic stress factors. $P$. verrucosum was stimulated to produce more OTA under interacting matric stress with $\mathrm{CO}_{2}$ concentrations at both 25 and $30{ }^{\circ} \mathrm{C}$. In contrast, with solute stress, especially at 30 ${ }^{\circ} \mathrm{C} P$. verrucosum activity was inhibited by solute stress influencing OTA production. In contrast, under matric stress, especially at $-2.8 \mathrm{MPa}\left(=0.98 \mathrm{a}_{\mathrm{w}}\right)$ and to some extent at -7.0. $\mathrm{MPa}$ $\left(=0.95 \mathrm{a}_{\mathrm{w}}\right)$ there was a stimulation of OTA. This was consistent with the effects noted in the gene expression responses, especially for the otapksPv gene. 
In conclusion this study has highlighted, for the first time, the impact of three-way interacting climate-related abiotic factors on growth, key OTA biosynthetic genes and OTA production by an important ochratoxigenic Penicillium species which contaminates temperate cereals post-harvest. This well studied strain of $P$. verrucosum was shown to be quite resistant to the imposed interacting climate-related abiotic factors in terms of growth rate and expression of OTA biosynthetic genes, especially in relation to matric stress. This type of data is important in understanding the life cycle of this species and its potential resilience under present and future climate change scenarios. This could also contribute to the development of models for the relative risks of OTA contamination in temperate cereal chains and developing effective intervention strategies to reduce inoculum potential in soil and on cereal crop residue.

\section{Acknowledgements}

S.A. is grateful to the British Council and the Newton Musharraf Programme for financial support.

\section{References}

Abdelmohsen, S, Verheecke-Vaessen, C, Garcia-Cela, E, Medina, A, Magan, N, 2020. Solute and matric potential stress on Penicillium verrucosum: impact on growth, gene expression and ochratoxin A production. World Mycotoxin J. 13, 345-353. https://doi.org/10.3920/WMJ2019.2542

Cairns-Fuller, V, Aldred, D, Magan, N, 2005. Water, temperature and gas composition interactions affect growth and ochratoxin A production by isolates of Penicillium verrucosum on wheat grain. J. Appl. Microbiol. 99, 1215-1221.

Cervini, C, Verkeecke-Vaessen, C, Ferraraa, M, García-Cela, E, Magistàa, D, Medina, A, Gallo, A, Magan, N, Perrone, G, 2020. Interacting climate change factors $\left(\mathrm{CO}_{2}\right.$ and temperature cycles) on growth, secondary metabolite gene expression and phenotypic ochratoxin A production by Aspergillus carbonarius strains on a grape-based matrix. Fungal Biol. In Press.

Elmholt, S, 2003. Ecology of the ochratoxin A producing Penicillium verrucosum: occurrence in field soil an grain with special attention to farming system and on-farm frying practices. Biol. Agric. Hortic. 20, 311-337.

Elmholt, S, Hostbjerg, H, 1999. Field ecology of the ochratoxin A-producing Penicillium verrucosum: survival and resource colonisation in soil. Mycopathologia 147, 67-81.

European Union, 2006. Commission Regulation EC No 1881/2006 19 December 2006 setting maximum levels for certain contaminants in foodstuffs.

Garcia-Cela, E, Verheecke-Vaessen, C, Gutierrez-Pozo, M, Kiaitsi, E, Gasperini, AM, Magan, $\mathrm{N}$, Medina, A, 2020. Unveiling the effect of interacting forecasted abiotic factors on growth and Aflatoxin $\mathrm{B}_{1}$ production kinetics by Aspergillus flavus. Fungal Biol. In Press.

Geisen, R., Schmidt-Heydt, M., Karolewiez, A., 2006. A gene cluster of the ochratoxin A biosynthetic genes in Penicillium. Mycotoxin Res. 22, 134141.

Giorni, P, Battilani, P, Magan, N, 2008. Effect of solute and matric potential on in vitro growth and sporulation of strains from a new population of Aspergillus flavus isolated in Italy. Fungal Ecol. 1, 102-108.

International Agency for Research on Cancer. 1993. Ochratoxin A (Class 2b). Volum 56, p. 489.

Jurado, M, Marın, P, Magan, N, Gonzalez-Jaen, M, 2008. Relationship between solute and matric potential stress, temperature, growth, and FUM gene expression. Appl. Environ. Microbiol. 74, 2032-2036. 
Leite, GM, Medina, A, Magan, N, 2012. Comparison of different bead-beating RNA extraction strategies: An optimized method for filamentous fungi. J. Microbiol. Meth. 88, 413-418.

Leite, G, 2013. Potential for control of spoilage and mycotoxigenic species using mixtures of anti-oxidants, aliphatic acids and molecular approaches using RNAi. PhD Thesis, Cranfield University, United Kingdom.

Lindblad, M, Johnsson, P, Jonsson, N, Lindqvist, R, Olsen, M, 2004. Predicting non-compliant levels of ochratoxin A in cereal grain from Penicillium verrucosum counts. J. Appl. Microbiol. 97, 609-616.

Lund, F, Frisvad, JC, 2003. Penicillium verrucosum in wheat and barley indicates presence of ochratoxin A. J. Appl. Microbiol. 95, 1117-1123.

Magan, N, 1988. Effect of water potential and temperature on spore germination and germ tube growth in vitro and on straw leaf sheaths. Trans. Brit. Mycol. Soc. 90, 97-107.

Magan, N, Aldred, D, 2007. Post-harvest control strategies: minimizing mycotoxins in the food chain. Int. J. Food Microbiol. 119, 131-139.

Medina, A, Magan, N, 2010. Comparison of water activity and temperature impacts on growth of Fusarium langsethiae strains from northern Europe on oat-based media. Int. J. Food Microbiol. 142, 365-369.

Medina, A, Akbar, A, Baazeem, A, Rodriguez, A, Magan, N, 2017. Climate Change, Food Security and Mycotoxins: Do We Know Enough? Fungal Biol. Rev. 31, 143-154.

Ramos, AJ, Magan, N, Sanchis, V, 1999. Osmotic and matric potential effects on growth, sclerotia and partitioning of polyols and sugars in colonies and spores of Aspergillus ochraceous. Mycol. Res. 103, 141-147.

Rodríguez, A, Rodríguez, M, Luque, MI, Justesen, AF, Córdoba, JJ, 2011. Quantification of Ochratoxin A-Producing Molds in Food Products by SYBR Green and TaqMan RealTime PCR Methods. Int. J. Food Microbiol. 149, 226-235.

Rodríguez, A, Medina, Á, Córdoba, JJ, Magan, N, 2014. The influence of salt $(\mathrm{NaCl})$ on ochratoxin A biosynthetic genes, growth and ochratoxin A production by three strains of Penicillium nordicum on a dry-cured ham-based medium. Int. J. Food Microbiol. 178, 113-119.

Ramirez, ML, Chulze, SN, Magan, N, 2004. Impact of osmotic and matric water stress on germination, growth, mycelial water potentials and endogenous accumulation of sugars and sugar alcohols in Fusarium graminearum. Mycologia 96, 470-478.

Schmidt-Heydt, M, Baxter, ES, Geisen, R, Magan, N, 2007. Physiological relationship between food preservatives, environmental factors, ochratoxin and otapks $\mathrm{Pv}$ gene expression by Penicillium verrucosum. Int. J. Food Microbiol. 119, 277-283.

Schmidt-Heydt, M, Baxter, ES, Geisen, R, Magan, N, 2007. Physiological relationship between food preservatives, environmental factors, ochratoxin and otapks $\mathrm{Pv}$ gene expression by Penicillium verrucosum. Int. J. Food Microbiol. 119, 277-283.

Schmidt-Heydt, M, Magan, N, Geisen, R, 2008. Stress induction of mycotoxin biosynthesis genes in relation to abiotic factors. FEMS Microbiol. Letts. 284, 142-149.

Steuter, AA, Mozafar, A, Goodin, JR, 1981. Water potential of aqueous polyethylene glycol. Plant Phys. 67, 64-67.

Verheecke-Vaessen, C, Diez-Gutierrez, L, Renaud, J, Sumarah, M, Medina, A, Magan, N, 2019. Interacting climate change environmental factors effects on Fusarium langsethiae growth, expression of TRI genes and T-2/HT-2 mycotoxin production on oat-based media and in stored oats. Fungal Biol. 23, 617-623.

Wang, Y, Wang, L, Liu, F, Wang, Q, Selvaraj, JN, Xing, F, Zhao, Y, Liu, Y, 2016. Ochratoxin A producing fungi, biosynthetic pathway and regulatory mechanisms. Toxins $8,1-1$. 